\title{
PENGARUH SISTEM OLAH TANAH TERHADAP EMISI GAS CO2TANAH BEKAS LAHAN ALANG-ALANG (Imperata cylindrica) YANG DITANAMI KEDELAI (Glycine max L) PADA MUSIM KEDUA
}

\author{
Shela Tiara Putri, Henrie Buchari, M. A. Syamsul Arif \& Dermiyati \\ Jurusan Agroteknologi, Fakultas Pertanian Universitas Lampung \\ Jl. Prof. Dr. Soemantri Brodjonegoro no. 1 Bandar Lampung 35145 \\ Email: d'rhanchel@yahoo.com
}

\begin{abstract}
ABSTRAK
Penelitian ini bertujuan untuk mengetahui pengaruh sistem olah pada lahan alang-alang (Imperata cylidrica) terhadap emisi $\mathrm{CO}_{2}$ tanah yang ditanami kedelai (Glycine max $\mathrm{L}$ ) pada musim ke dua.Penelitian ini dilakukan dengan menggunakan rancangan acak kelompok (RAK) dengan perlakuan 3 sistem olah tanah, TOT = Tanpa Olah Tanah, OTM = Olah Tanah Minimum, OTI = Olah Tanah Intensif, dengan 6 kali ulangan. Tanaman kedelai digunakan sebagai indikator respon perlakuan yang diterapkan. Data yang diperoleh diuji homogenitasnya, dengan uji Bartlett dan aditifitas diuji dengan uji Tukey. Data dianalisis dengan sidik ragam dan dilanjutkan dengan Uji BNT 5\%. Dari hasil analisis ragam menunjukkan bahwa pengamatan hari ke-1, hari ke21, dan hari ke-47 tidak memberikan pengaruh yang nyata terhadap emisi $\mathrm{CO}_{2}$ tanah. Namun pengamatan hari ke-78, sistem olah tanah memberikan pengaruh yang sangat nyata terhadap emisi $\mathrm{CO}_{2}$ tanah, dan berpengaruh nyata pada hari ke-114 setelah pengolahan tanah. Berdasarkan hasil uji BNT 5\% emisi gas $\mathrm{CO}_{2}$ tanah pada sistem TOT lebih rendah dibandingkan dengan sistem OTM dan sistem OTI serta terdapat korelasi antara emisi gas $\mathrm{CO}_{2}$ tanah dengan kapasitas tukar kation (KTK).
\end{abstract}

Kata kunci : Alang-alang (Imperata cylidrica), emisi gas $\mathrm{CO}_{2}$, kedelai (Glycine max $\mathrm{L}$ ), sistem olah tanah.

\section{PENDAHULUAN}

Lahan alang-alang (Imperata cylindrica) merupakan salah satu lahan yang potensial untuk peningkatan produksi pertanian khususnya tanaman pangan (Anny, 2005).Luas lahan alang-alang (Imperata cylindrica) di Indonesia pada awal 1990 adalah 8,6 juta hektar $(4,5 \%$ dari luas daratan). Lahan alang-alang yang terluas terdapat di Sumatera dan Kalimantan, yaitu masing-masing 2,13 dan 2,19 juta hektar. Luas lahan alang-alang di lampung sekitar 75.921 hektar (Abdul, 2006).

Menurut Fagi (2001), pemanfaatan lahan alangalang untuk usaha pertanian relatif lebih baik, karena memiliki kemampuan sebagai penyimpan karbon yang berfungsi dalam mengurangi pemanasan global. Pemanasan global pada abad 21 ini menjadi salah satu isu penting dunia karena berdampak pada perubahan iklim global (FAO, 2007). Pemanasan gobal sendiri terjadi sebagai akibat dari makin meningkatnya gas rumah kaca (GRK) di atmosfer yaitu $\mathrm{CO}_{2}, \mathrm{CH}_{4}$, dan $\mathrm{N}_{2} \mathrm{O}$ (MAF, 2006). Oleh karena itu akan terjadi peningkatan suhu di permukaan bumi yang menyebabkan pemanasan global. Upaya minimasi emisi gas rumah kaca menjadi salah satu upaya yang mendapat perhatian besar dalam pengelolaan lingkungan.Emisi $\mathrm{CO}_{2} \operatorname{tanah}$ merupakan komponen penting dari siklus karbon global, yang pada dasarnya dikendalikan oleh dua proses, yaitu $\mathrm{CO}_{2}$ produksi dalam tanah dan transportasi dari tanah ke atmosfer (Ball and pretty, 2002). Aktivitas mikroba dan respirasi akar merupakan sumber utama produksi $\mathrm{CO}_{2}$, dan transportasi gas diatur oleh difusi. Suhu tanah dan kadar air tanah, atau interaksi antara keduanya, merupakan faktor utama yang mengendalikan variabilitas respirasi tanah (Syahrinuddin, 2005).

Usaha untuk meningkatkan produksi tanaman pangan dapat dilakukansalah satunya dengan cara penerapan sistem olah tanah yang benar dan tidak menimbulkan akibat yang buruk pada jangka pendek maupun pada jangka panjang.Pertanian konservasi memperkenalkan olah tanah konservasi (conservation tillage) dalam bentuk olah tanah minimum (OTM), tanpa olah tanah (TOT) dan pemanfaatan mulsa. Peralihan dari praktik olah tanah konvensional menuju olah tanah konservasi secara meluas akan memberikan sumbangan yang besar dalam peningkatan deposit karbon di dalam tanah, yang secara langsung akan meningkatkan kesuburan tanah, serta mengurangi emisi gas metana di 
atmosfer. Hal ini dapat menjadi suatu kontribusi sektor pertanian yang sangat berarti dalam upaya mitigasi resiko dari perubahan iklim akibat pemanasan global (Johanis, 2008).

\section{BAHAN DAN METODE}

Penelitian ini dilaksanakan pada bulan juli 2012 sampai dengan bulan oktober 2012 di daerah Blora Indah kelurahan Segala Mider, Tanjung Karang Barat, Bandar Lampung. Alat-alatyang digunakan adalah cangkul, timbangan, kantung plastik, soil moisture (mengukur kelembaban tanah), soil temperature (mengukur suhu tanah), spidol, toples plastik ukuran $1 \mathrm{~kg}$, botol film, $\mathrm{pH}$ meter, labu ukur $1000 \mathrm{ml}$, stand buret, buret $50 \mathrm{ml}$, pipet tetes $10 \mathrm{ml}$, corong, timbangan, dan erlenmeyer $250 \mathrm{ml}$.

Bahan-bahan yang digunakan dalam penelitian ini adalah aquades, $\mathrm{KOH} 0,1 \mathrm{~N}, \mathrm{HCl}$, phenolphtalein, metil orange, kertas tisu, pupuk kimia (Urea, SP-18 dan $\mathrm{KCl}$ ), benih kedelai Tanggamus, dan herbisida glifosat. Penetapan pengukuran produksi emisi gas $\mathrm{CO} 2$ tanah dengan menggunakan metode Verstraete (Anas, 1989), C-organik (Walkey and Black), N-total (metode Kjeldahl) dan $\mathrm{pH}$ tanah (metode elektrometrik).

Penelitian ini dilakukan dengan menggunakan rancangan acak kelompok (RAK) yang terdiri atas 3 (tiga) perlakuan dan 6 (enam) ulangan, sehingga diperoleh 18 (delapan belas) satuan petak percobaan. Perlakuan yang diterapkan dalam penelitian ini adalah :

1. $\mathrm{T}_{0}=$ Tanpa Olah Tanah (TOT)

2. $\mathrm{T}_{1}=$ Olah Tanah Minimum (OTM)

3. $\mathrm{T}_{2}=$ Olah Tanah Intensif (OTI)

Pengambilan sampel tanah dilakukan sebelum pengolahan tanah, setelah olah tanah, masa fase vegetatif maksimum dan sebelum panen tanaman kedelai (Glycine $\max \mathrm{L}$.)

Lahan yang digunakan dalam penelitian ini merupakan lahan alang-alang usia lebih dari 10 tahun yang diberakan dan dipotong setiap satu bulan serta sisa atau serasah tanaman dibiarkan sehingga menjadi bahan organik. Lahan tersebut tidak pernah dilakukan pengolahan tanah dan penanaman tanaman, hingga penelitian musim pertama pada tahun 2010 .

Penelitian musim pertama dengan menggunakan sistem pengelolaan lahan dengan penggunaan tiga sistem olah tanah, yaitu tanpa olah tanah, olah tanah minimum, dan olah tanah intensif.Kemudian pada penelitian ini dilakukan penelitian lanjutan musim tanam kedua dengan menggunakan tanaman kedelai.

Sampel tanah diambil dengan menggunakan bor tanah dari lokasi penelitian. Contoh tanah diambil sebanyak lima titik setiap ulangan, sampai kedalaman
$20 \mathrm{~cm}$ disetiap titik pengambilan.Kemudian contoh tanah yang diambil pada setiap titik dikompositkan berdasarkan ulangan.Pengambilan sampel awal dilakukan sebelum pengolahan lahan.Pengambilan sampel tanah kedua, setelah pengolahan lahan, pengambilan sampel ketiga pada fase vegetatif maksimum dan pengambilan sampel keempat dilakukan satu hari sebelum panen.

Pada saat dua minggu sebelum pelaksanaan penelitian dilakukan pengukuran lahan dan pembuatan plot percobaan. Plot percobaandibuat secara kelompok, tiga perlakuan dan enam ulangan.Pada petak olah tanah intensif (OTI), pengolahan tanah dimulai dengan pembabatan alang-alang, kemudian tanah diolah sebanyak 2 kali. Mula-mula tanah dicangkul sedalam lebih kurang $20 \mathrm{~cm}$ secara merata, kemudian dilakukan penghancuran bongkahan pertama. Tanah diratakan dan sisa alang-alang dibuang dikeluarkan dari petak percobaan.

Pada olah tanah minimum (OTM) lahan tidak disemprot menggunakan herbisida tetapi hanya dilakukan pembabatan gulma, dan pengolahan tanah seperlunya yaitu hanya setebal $10 \mathrm{~cm}$, kemudian sisa tanaman gulma (alang-alang) digunakan sebagai mulsa. Sedangkan pada petak tanpa olah tanah (TOT), pengolahan tanah tidak dilakukan,namun dilakukan pembuatan lubang tanam untuk peletakan benih. Selanjutnya gulma yang tumbuh, dikendalikan dengan menggunakan herbisida, kemudian sisa gulma dikembalikan ke lahan sebagai mulsa.

Emisi $\mathrm{CO}_{2}$ diukur 1 hari sebelum olah tanah, setelah pengolahan tanah, pada saat masa vegetatif maksimum pada hari ke- 78 dan selanjutnya dilakukan saat masa panen tiba pada hari ke- 114. Pengukuran emisi $\mathrm{CO}_{2}$ dilakukan dengan menutup permukaan tanah menggunakan toples yang didalamnya telah diberikan botol film yang berisi $10 \mathrm{ml} \mathrm{KOH} \mathrm{0,1} \mathrm{N}$.

Untuk kontrol dilakukan hal yang sama, tetapi permukaan tanah ditutup dengan plastik sehingga $\mathrm{KOH}$ tidak dapat menangkap $\mathrm{CO}_{2}$ yang keluar dari tanah. Pengukuran ini dilakukan selama 2 jam pada pukul 12.0014.00. Pengukuran emisi $\mathrm{CO}_{2}$ dilakukan secara duplo, yaitu dengan 4 buah toples pada setiap petak percobaan, dimana 2 toples sebagai kontrol dan 2 lainnya sebagai perlakuan.

Setelah pengukuran dilapangan selesai $\mathrm{KOH}$ hasil pengukuran dititrasi di laboratorium untuk menentukan kuantitas $\mathrm{C}-\mathrm{CO}_{2}$ yang dihasilkan. Titrasi dilakukan dengan cara memindahkan $\mathrm{KOH}$ hasil pengukuran kedalam gelas beaker dan ditambahkan 2 tetes fenolptalin, sehingga warna berubah menjadi merah muda dan kemudian dititrasi dengan $\mathrm{HCl}$ sampai warna merah muda hilang (larutan berwarna bening), volume 
$\mathrm{HCl}$ yang diperlukan dicatat. Kemudian ke dalam larutan ditambahkan 2 tetes metil orange sehingga larutan berwarna orange, dan larutan dititrasi kembali dengan $\mathrm{HCl}$ hingga warna orange berubah menjadi warna merah muda. $\mathrm{HCl}$ yang digunakan berhubungan langsung dengan jumlah $\mathrm{CO}_{2}$ yang difiksasi.

Variabel pendukung yang diamati pada akhir $( \pm 114$ hari) adalah :

1. Analisis C-organik (metode Walkley dan Black )

2. Reaksi tanah/pH (metode elektrometrik)

3. Suhu tanah $\left({ }^{\circ} \mathrm{C}\right)$ (alat soil temperature)

4. Kelembaban tanah (\%) (alat soil moisture)

5. Kapasitas tukar kation (me/100g)

Data yang diperoleh diuji dengan menggunakan analisis ragam. Sebelum analisis ragam, homogenitas data diuji dengan uji Barlet dan aditifitas data dengan uji Tukey, kemudian dilakukan juga uji korelasi antara variabel utama dengan variabel pendukung. Setelah itu dilakukan uji lanjut dengan uji Beda Nyata Terkecil (BNT) taraf $5 \%$.

\section{HASIL DAN PEMBAHASAN}

Berdasarkan hasil uji BNT5\% emisi $\mathrm{CO}_{2}$ tertinggi diperoleh pada sistem olah tanah intensif, sedangkan emisi $\mathrm{CO}_{2}$ terendah pada sistem tanpa olah tanah. Sistem olah tanah berpengaruh nyata terhadap emisi $\mathrm{CO}_{2}$ tanah pada pengamatan hari ke-78 dan hari ke114.Pada sistem olah tanah intensif tanah dibajak dan sisa gulma serta tanaman tidak dikembalikan kelahan. Pengolahan tanah yang dilakukan secaraintensif kadar oksigen dalam tanah akan meningkat dan dapat memperbaiki aerasi, sehingga oksigen akan mudah

Tabel 1. Pengaruh sistem olah tanah terhadap emisi $\mathrm{CO}_{2}$ $\left(\mathrm{kg} \mathrm{CO}_{2}\right.$ ha $^{-1}$ hari $\left.^{-1}\right)$

\begin{tabular}{|c|c|c|c|}
\hline \multirow{3}{*}{ Perlakuan } & \multicolumn{3}{|c|}{ Emisi $\mathrm{CO}_{2}\left(\mathrm{~kg} \mathrm{CO}_{2}\right.$ ha $^{-1}$ hari $\left.^{-1}\right)$} \\
\hline & \multicolumn{3}{|c|}{ Waktu Penga matan (HSP) } \\
\hline & 78 & \multicolumn{2}{|c|}{114} \\
\hline OTI & $115,4 \quad \mathrm{a}$ & 114,1 & $\mathrm{a}$ \\
\hline OTM & $67,7 \mathrm{ab}$ & 101,3 & b \\
\hline TOT & $54,8 \quad$ b & 77,9 & b \\
\hline BNT 5\% & 24,5 & & \\
\hline
\end{tabular}

Keterangan : Angka yang diikuti oleh huruf yang sama tidak berbeda nyata dengan uji BNT pada taraf nyata $5 \%$, TOT = Tanpa Olah Tanah; OTM = Olah TanahMinimum; OTI $=$ Olah Tanah Intensif . masuk ke dalam tanah. Peningkatan kadar oksigen dalam tanah dapat meningkatkan aktivitas biota tanah untuk mendekomposisi bahan organik organic (Fernando, 2010). Hasil uji BNT 5\% (Tabel 1) menunjukan bahwa pada hari ke-78, dan 114 setelah olah tanah secara konsisten rata-rata emisi $\mathrm{CO}_{2}$ tertinggi terjadi pada perlakuan sistem olah tanah intensif, dan rata-rata emisi $\mathrm{CO}_{2}$ terendah terjadi pada perlakuan tanpa olah tanah. Dari hasil uji statistik menunjukkan bahwa emisi $\mathrm{CO}_{2}$ tanah padapengamatan hari ke-1, 21, dan 47 tidak berbeda nyata dengan berbagai sistem olah tanah.Pada pengamatan hari ke-78 dan $114 \mathrm{CO}_{2}$ sangat berbeda nyata dengan berbagai sistem olah tanah. Berdasarkan hasil uji BNT 5\% sistem pengolahan tanah berpengaruh terhadap emisi $\mathrm{CO}_{2}$ pada pengamatan hari ke-78 dan 114 setelah pengolahan tanah.

Pada sistem olah tanah intensif kondisi lingkungannya mendukung aktivitas mikroba dalam merombak bahan organik. Semakin tinggi aktivitas mikroba tanah semakin cepat proses dekomposisi bahan organik berlangsung, sehingga mineralisasi unsur berlangsung cepat, termasuk pelepasan emisi $\mathrm{CO}_{2} \mathrm{ke}$ udara. Selain itu, pengolahan tanah bukan hanya membalik tanah dan membuka tanah sehingga memacu oksidasi dan aliran gas $\mathrm{CO}_{2}$, tetapi juga membuat permukaan tanah porus sehingga mempercepat pelepasan gas $\mathrm{CO}_{2}$ Dengan meningkatnya aliran oksigen (oxygen flux), respirasi dan aktivitas mikroba dekomposer meningkat yang akan menghasilkan gas buangan $\mathrm{CO}_{2}$, yang pada akhirnya melalui tanah yang gembur akan dilepaskan ke udara berupa emisi gas $\mathrm{CO}_{2}$. Sebaliknya pada TOT, permukaan tanah tidak diganggu sama sekali kecuali lubang tugalan mengakibatkan ekspose tanah terhadap oksigen tidak terlalu banyak, sehingga respirasi tanah tidak banyak terjadi (Reicosky, 2000).

Pada Tabel 2 pengaruh sistem olah tanah terhadap emisi $\mathrm{CO}_{2}$ yang dihasilkan tidak memberikan pengaruh yang nyata pada hari ke-1, hari ke-21, hari ke-47, namun pada pengamatan hari ke-78, dan hari ke-114 setelah olah tanah memberikan pengaruh yang sangat nyata terhadap $\mathrm{CO}_{2}$ tanah. Menurut Anas (1989), pengolahan tanah dangkal tidak besar pengaruhnya terhadap aktifitas mikroorganisme, hal ini yang menyebabkan pada sistem olah tanah minimum emisi $\mathrm{CO}_{2}$ tanah yang diukur dari respirasi mikroorganisme tanah tidak begitu tinggi pada hari pertama. Sedangkan pada saat tanaman memasuki masa fase vegetatif maksimum respirasi yang dihasilkan tinggi.Hal ini diduga karena pengaruh vegetasi tanaman yang berada pada fase vegetatif maksimum juga mempengaruhi meningkatnya emisi $\mathrm{CO}_{2}$ tanah yang berasal dari eksudat akar yang meningkat. Semakin 
Tabel 2. Ringkasan signifikasi analisis ragam pengaruh sistem olah tanah terhadap emisi $\mathrm{CO}_{2} \operatorname{tanah}\left(\mathrm{kg} \mathrm{C}-\mathrm{CO}_{2}\right.$ ha $^{-1}$ hari $^{-1}$ ) bekas lahan alang-alang (Imperata cylindrica) yang ditanami kedelai (Glycine max L.) pada pengamatan sesudah pengolahan tanah akibat pengaruh sistem olah tanah.

\begin{tabular}{|c|c|c|c|c|c|}
\hline \multirow{3}{*}{ Variabel Pengamatan } & \multicolumn{5}{|c|}{ Emisi $\mathrm{CO}_{2}\left(\mathrm{~kg} \mathrm{C}-\mathrm{CO}_{2}\right.$ ha $^{-1}$ hari $\left.^{-1}\right)$} \\
\hline & \multicolumn{5}{|c|}{ Waktu Pengamatan (HSP) } \\
\hline & 1 & 21 & 47 & 78 & 114 \\
\hline Sis tem Olah Tanah (SOT) & tn & $\operatorname{tn}$ & $\operatorname{tn}$ & $* *$ & $*$ \\
\hline
\end{tabular}

Keterangan : $\mathrm{tn}=$ tidak berpengaruh nyata; $*=$ berpengaruh nyata; $* *=$ berpengaruh sangat nyata pada taraf $5 \% ; \mathrm{HSP}=$ hari setelah pengolahan tanah.

Tabel 3. Ringkasan uji korelasi antara emisi $\mathrm{CO}_{2}$ tanah dengan $\mathrm{pH}$ tanah, C-organik tanah, N-total tanah, suhu tanah dan kelembaban tanah pada saat panentanaman kedelai (Glycine max L.).

\begin{tabular}{cccccc}
\hline \multirow{2}{*}{ Korelasi } & \multicolumn{5}{c}{ Koefisien korelasi (r) } \\
\cline { 2 - 6 } & $\mathrm{pH}$ tanah & C-organik & Suhu & Kelembaban & KTK \\
\hline Emisi $\mathrm{CO}_{2}$ tanah & $-0,15^{\text {tn }}$ & $-0,11^{\text {tn }}$ & $0,03^{\text {tn }}$ & $-0,14^{\text {tn }}$ & $-0,58^{* *}$ \\
\hline
\end{tabular}

Keterangan $:$ tn $=$ tidak berbeda nyata; $*$ = berbeda nyata pada taraf $5 \%$.

tinggi jumlah biomassa mikroorganisme tanah maka jumlah bahan organik yang disintesis semakin tinggi juga, sehingga dapat menghasilkan unsur hara yang dapat digunakan untuk tanaman (Hakim dkk., 1986).

Tabel 3 hasil uji korelasi menunjukkan bahwa kapasitas tukar kation (KTK) berpengaruh nyata terhadap emisi $\mathrm{CO}_{2}$. Hal ini diduga karena pada pengolahan tanah secara konservasi maupun secara konvensional terdapat bahan organikyangmempengaruhi kapasitas tukar kation didalam tanah. Kapasitas tukar kation merupakan sifat kimia yang sangat erat hubungannya dengan kesuburan tanah.Pengaruh bahan organik terhadap KTK tanah juga berpengaruh sangat nyata, karena terdapat daya jerap bahan organik. Bahan organik juga dapat menghasilkan humus yang mempunyai KTK jauh lebih tinggi daripada mineral liat. Oleh karena itu semakin tinggi kandungan bahan organik tanah semakin tinggi pula nilai KTK-nya (Arifin, 2013).

\section{KESIMPULAN}

Dari penelitian ini dapat disimpulkan bahwa emisi gas $\mathrm{CO}_{2}$ tanah pada sistem Olah Tanah Intensif (OTI) lebih tinggi dibandingkan dengan sistem Olah Tanah Minimum (OTM) dan sistem Tanpa Olah Tanah (TOT) dan terdapat korelasi negatif antara emisi gas $\mathrm{CO}_{2}$ tanah dengan kapasitas tukar kation (KTK) tanah.

\section{DAFTAR PUSTAKA}

Abdul, H.M. 2006. Motif Pembakaran Lahan AlangAlang (Imperata cylindrica) Di daerah Tapanuli Selatan. Institut Pertanian Bogor. Bogor. $10 \mathrm{hlm}$.

Anas, I. 1989. Biologi Tanah dalam Praktek. Departemen Pendidikan dan Kebudayaan Direktorat Jendral Pendidikan Tinggi Pusat antar Universitas Bioteknologi. Institut Pertanian Bogor. $161 \mathrm{hlm}$.

Arifin, R. 2013. Kapasitas Tukar Kation. http/ blogspot.com. Diakses pada tanggal : 15 Agustus 2013.

Ball, A. S. dan J. N. Pretty. 2002. Agricultural Influences on Carbon Emissions and Sequestration. University of Essex. Wivenpark, Colchester, UK.

Fagi, A. 2008. Laporan tahunan, Konsorsium penelitian dan pengembangan perubahan iklim pada sektor pertanian. Balai Pesar Penelitian dan Pengembangan Sumberdaya Lahan Pertanian, Bogor. Sequestration in Soil, Lal, R., Kimble, J., and Follet, R. (eds). Penyerapan dalam Tanah, R. Lal, Kimble, J., dan Follett,, R. (eds). 
CRC Press, Boca Raton, Florida, pp. CRC Press, Boca Raton, Florida.

FAO. 2007. Carbon Sequestration in Dry Land Soil. Natural Resources Management and Environment Departement.

Fernando, L. K. 2010. Pengaruh Olah Tanah Konservasi Jangka Panjang Terhadap Penyerapan Karbon Dan Emisi Gas $\mathrm{CO}_{2}$ Pada Lahan Pertanaman Jagung Di Tanah Ultisol. (Skripsi). Universitas Lampung. Bandar Lampung. Hal. 23.

Hakim, N., M.Y. Nyakpa, A.M. Lubis, S.G. Nugroho, R. Saul, A. Diha, B.H.Go, dan H.H. Bailey. 1986. Dasar-Dasar Ilmu Tanah. Universitas Lampung. Bandar Lampung. $488 \mathrm{hlm}$.

Johannis, M. L. 2008. Pemanasan Global Dan Pertanian Konservasi. http://sinarharapan. go.id. Diakses pada tanggal : 9 September 2012.
MAF. 2006. Suistainable Land Management and Climate Change. Option for Plan of Action.New Zealand Government Initiative on Suistainability.

Mulyani, A. 2005. Teknologi Untuk Menyulap Lahan Alang-Alang Menjadi Lahan Pertanian. http:/ Inovakusuma.wordpress.com. Diakses pada tanggal : 24 September 2013

Reicosky, D. 2000. Conservation Tillage and Carbon Cycling : Soil as a Source or Sink for Carbon. USDA-Agricultural Research Service, North Central Soil Conservation Research Laboratory, USA.

Syahrinuddin. 2005. The potential of oil palm and forest plantations for carbon sequestration on degraded land in Indonesia. Ecology and Development Series No. 28. Cuvillier Verlag Göttingen. 